\title{
EVALUATING EFFECTIVENESS OF PAYMENTS FOR FOREST ECOSYSTEM SERVICES BY PROPENSITY SCORES ANALYSIS
}

\author{
Huynh Tan Nguyen ${ }^{1}$, Nguyen Hoang Hung ${ }^{2}$ \\ *Corresponding author E-mail: huynhtannguyen@dntu.edu.vn
}

\begin{tabular}{l} 
A R T I C L E I N F O \\
Original Article \\
Received: 23 January 2020 \\
Accepted: 21 February 2020 \\
doi:10.5937/ekoPolj2001087N \\
UDC 330.342:502.131.1 \\
\hline
\end{tabular}

Keywords:

Propensity scores, payments for forest ecosystem services, Average Treatment Effect on Treated, Average Treatment Effect, Difference-to-differences approach

JEL: Q18, Q23, R23

\section{A B S T R A C T}

The Vietnamese Government have been implementing the Payment for Forest Ecosystem Service (PFES) since 2008 with the aim of both improving natural forest status and enhancing income for mountainous community. Yet, effectiveness of the PFES scheme is now debated because of the shortage of experimental studies. So, the overall purpose of this study is to measure the effectiveness of the PFES program by propensity scores analysis. To do so, the study randomly surveyed 469 households located in four districts across Quang Nam province and then estimated the Average Treatment Effect on Treated (ATET). It is found that: (1) the households within PFES had got a insignificantly higher income than those without PES in the short-run; (2) yet, PFES was effective in long-run due to the improvement on income for participants; (3) PFES had an important role in increasing income inequality. Although this study demonstrated reasonable results, some limitations still exist due to the objective reasons, thus more studies with alternative methods should be conducted to confirm the results of this study for better policies.

(C) 2020 EA. All rights reserved.

\section{Introduction}

The forest ecosystem (ES) has been providing a wide range of important benefits to human beings so far, including water provision, carbon sequestration, biodiversity improvements, farmland abandonment restoring, water and air purification, production raw materials, as well as social and cultural values such as recreation, traditional resource uses and spirituality (Ruggiero, Metzger, Tambosi, \& Nichols, 2019; Wang,

1 Huynh Tan Nguyen, PhD candidate, Dong Nai Technology University, Nguyen Khuyen Street, Quarter 5, Trang Dai Ward, Bien Hoa City, Dong Nai Province, Viet Nam, phone number: (+84)914698757, email: huynhtannguyen@dntu.edu.vn, ORCID ID (https://orcid. org/0000-0002-9638-7347)

2 Nguyen Hoang Hung, PhD candidate, Dong Nai Technology University, Nguyen Khuyen Street, Quarter 5, Trang Dai Ward, Bien Hoa City, Dong Nai Province, Viet Nam, phone number: (+84)909462818, email: nguyenhoanghung@dntu.edu.vn, ORCID ID (https:// orcid.org/0000-0003-1655-1600) 
Bilsborrow, Zhang, Li, \& Song, 2019). Thus, Jespersen and Gallemore (2018) and Treacy, Jagger, Song, Zhang, and Bilsborrow (2018) emphasized that the degradation of the forest ecosystem will definitely affect all objects of the economy and might result in sophisticated changes, both economically and socially. In fact, ES gives the way of life for local communities by so many different kinds of plants and animals originating from the forests, that is why Watson et al. (2018) argue that maintaining and restoring the integrity of forest ecosystem services is a high priority to limit the growing biodiversity crisis, slow down continuing climate change as well as accomplish sustainable development targets. In Vietnam, to hinder the forest ecosystem degradation, the Vietnamese government has been implementing a national program nationwide since 2008, called Payments for Forest Ecosystem Services (PFES), yet there is the shortage of ex post assessment to measure effectiveness and sustainability of this scheme. Although some current studies assess the effect of intervention schemes on local livelihoods as well as explore the determinants of scheme participation, a little literature show clear evidences about total income of households and use robust methods. Hence, to estimate the impact of PFES schemes as well as potential unplanned outcomes, it is necessary to investigate the depth, the extent, and allocations of the effects of conservation intervention over many period of time (Beauchamp, Clements, \& Milner-Gulland, 2018).

Presently a large number of empirical studies demonstrate the effectiveness of PES projects on the environment including land loss reduction and forest coverage improvement, whereas the positive impacts of PES schemes on local livelihoods, income increase and poverty alleviation have been debated. Zhou, Wang, and Wang (2019) posit that there is considerable trade-off between the objectives of environmental conservation and social-economic growth, hence when implementing PES policy makers should focus on only one target either environmental or socialeconomic objectives. This argument is consistent with the argument of Arriagada, Sills, Ferraro, and Pattanayak (2015) that although the conservation programs have positive influence on environmental outcomes (i.e. forest cover, land loss and biodiversity), the improvement in household assets or well-being is insignificant because the PES programs not only decrease two main on-farm inputs (cattle and hired labor), but also pay a small amount of cash to each household for daily expenses.

The studies on the effect of PES programs on household prosperity display different results, with both positive and negative outcomes regarding total income, well-being and total assets (Alix-Garcia, McIntosh, Sims, \& Welch, 2013; Q. Li \& Zander, 2019). The reason for this situation is explained that the effect of PES is able to strongly rely on the specific context of study site and household characteristics, implying that the PES implementation does not definitely make improvements on livelihoods and total income for participants as planned. Empirical studies of Clements and MilnerGulland (2015), Alix-Garcia et al. (2013), Hanauer and Canavire-Bacarreza (2015) argue conservation interventions having neither substantial influence on income nor considerable contributions to poverty reduction at the community level. In addition, 
Beauchamp et al. (2018) add that protected areas might be able to improve local traditional livelihoods, yet reduce households' socio-economic status, in spite of not hampering the progress. These arguments are in line with socio-economic assessments of Manjula, Venkatachalam, Mukhopadhyay, and Kumar (2019) who illustrate that such conservation actions may lead to negative influence on livelihoods of local residents, for example, increased production cost, unstable crop productivity, and thereby increase social pressure because of unequal distribution of benefits.

On the contrary, the research of Birte Snilstveit et al. (2019) argue that PES schemes have significantly positive influences on socio-economic outcomes such as strengthening the knowledge of locals and shifting the economic structure, and on measures of overall income of participants, but do not have an impact on income from off-farm activities such as tourism, hired labor as well as handicrafts. Additionally, PES schemes in Mexico are demonstrated to improve community income by both creating more off-farm jobs and diversifying income sources from agricultural activities such as crop planting, cattle rearing and the timber products harvesting (Costedoat, 2017). The studies of Hanauer and Canavire-Bacarreza (2015), Ruggiero et al. (2019), and Beauchamp et al. (2018) have also suggested that the payments from PES programs might be too low to develop total local income and to enhance the standard of living, whereas such PES programs have the role of changing community skills, knowledge as well as attitude towards the functionality of forest conservation, and providing a lot of other income streams namely forest services and rural non-agricultural employment.

In Vietnam nowadays, to the best of our knowledge, there are a few household-level studies exploring the roles of PFES programs on community livelihoods and the standard of living. To date, some current studies of Pham et al. (2013), Asian Development Bank (2014), Do, Vu, and Catacutan (2018), and Vietnam Administration of Forestry (2019) investigated the challenge of applications of PFES in Vietnam, yet one of the key limitations is that most studies have not examined factors influencing the participation of PFES yet, analyzed results are mainly descriptive statistics by describing the basic features of data instead of using econometric models to interfere and test the research hypothesis, and thereby lack methodological robustness. To end the mentioned-above debates, we carry out in-depth interviews with rural household where PFES scheme is being implemented with the aim of evaluating effectiveness of PFES over a period of 10 years (from 2010 to 2019), before and after PFES was introduced in the study region.

We concentrate on answering the following research questions (1) How is the influence of the PFES program on the livelihood outcome in terms of total income, the change in total income as well as the change in income inequality? (2) What are the implications for designing PFES schemes in the context of tropical countries in the future? This study's contribution is to fill the literature gap of PFES in terms of social-economic evaluation by using the propensity scores analysis which is quite rarely in currently PES-related studies and has also never been applied for PES-related researches in Vietnam before. 
This research proceeds as follows: Section 2 introduces the overview about the PFES scheme in Vietnam; section 3 presents the method used in this study consisting of the study site, sampling and survey methods, data analysis and data validation; section 4 displays results and discussion of the empirical research; and the last section of this study, the main conclusions are summarized, and the policy implications of the research work are presented.

Table 1. The impact of PES on the local livelihoods

\begin{tabular}{|c|c|c|c|}
\hline Authors & Study region & Methods & Livelihood outcomes \\
\hline $\begin{array}{l}\text { Beauchamp et al. } \\
\text { (2018) }\end{array}$ & $\begin{array}{c}\text { The Northern Plains of } \\
\text { Cambodia }\end{array}$ & $\begin{array}{l}\text { Multi-period impact } \\
\text { evaluation }\end{array}$ & $\begin{array}{l}\text { Decrease households' socio- } \\
\text { economic status }\end{array}$ \\
\hline $\begin{array}{l}\text { Birte Snilstveit et al. } \\
\text { (2019) }\end{array}$ & $\begin{array}{l}\text { China, Mexico, Costa } \\
\text { Rica, Ecuador }\end{array}$ & Meta-analysis & Positive effect on total income \\
\hline Zhou et al. (2019) & Anhui (China) & Survey & Reduce cultivated land \\
\hline $\begin{array}{c}\text { Hanauer and } \\
\text { Canavire-Bacarreza } \\
(2015)\end{array}$ & $\begin{array}{l}\text { Protected Areas } \\
\text { (Bolivia) }\end{array}$ & Quasi-experimental & $\begin{array}{l}\text { Uncertain impact on income } \\
\text { and poverty alleviation }\end{array}$ \\
\hline $\begin{array}{l}\text { Ruggiero et al. } \\
\qquad(2019)\end{array}$ & Atlantic Forest (Brazil) & $\begin{array}{l}\text { Propensity score } \\
\text { matching and } \\
\text { differences-in- } \\
\text { differences }\end{array}$ & $\begin{array}{l}\text { Little improvement on } \\
\text { financial outcomes } \\
\text { Inconsiderable progress in } \\
\text { diversifying off-farm jobs }\end{array}$ \\
\hline Pauline (2016) & Sub-Saharan Africa & Meta-analysis & $\begin{array}{l}\text { Extra income for poor } \\
\text { households } \\
\text { Additional profits for planting } \\
\text { crops } \\
\text { Decrease opportunity cost }\end{array}$ \\
\hline Costedoat (2017) & $\begin{array}{l}\text { Protected Areas in } \\
\text { Chiapas (Mexico) }\end{array}$ & Quasi-experimental & $\begin{array}{l}\text { Create more part-time jobs } \\
\text { Diversify agricultural } \\
\text { activities }\end{array}$ \\
\hline $\begin{array}{c}\text { Muttaqin, Alviya, } \\
\text { Lugina, and Hamdani } \\
\text { (2019) }\end{array}$ & $\begin{array}{l}\text { Customary and } \\
\text { Research Forests, } \\
\text { Nature Reserves, } \\
\text { National Parks } \\
\text { (Indonesia) }\end{array}$ & Qualitative approach & $\begin{array}{l}\text { Promote national tourism } \\
\text { Develop economic alternatives } \\
\text { Create off-farm jobs }\end{array}$ \\
\hline $\begin{array}{l}\text { Samii, Lisiecki, } \\
\text { Kulkarni, Paler, and } \\
\text { Chavis (2014) }\end{array}$ & $\begin{array}{l}\text { Mexico, Mozambique, } \\
\text { China, Costa Rica }\end{array}$ & Meta-analysis & $\begin{array}{l}\text { Little additional income } \\
\text { Little contributions to poverty } \\
\text { reductions } \\
\text { Insignificant welfare effects }\end{array}$ \\
\hline
\end{tabular}

Source: Summary from the previous studies 


\section{Overview of PFES in Vietnam}

Since 1990s, Vietnam has been actively shifting forest management and protection from exploitation to conservation of forests, especially native and national forests, after fairly rapid deforestation and degradation in the past decades. At the same time, several national forest schemes like Program 661 in 1998 and Program 327 in 1993 has been carried out across the country so far. Despite of so many achievements from these national programs, a large number of challenges still exist because of the shortage of mid and long-term funds and low disbursement rates. Hence, in an effort to improve and develop Vietnam's natural forest, the Vietnamese government set up Payments for Forest Environmental Services or Payments for Forest Ecosystem Services (PFES) in 2008 for the purpose of boosting the country's overall forest coverage up to $42 \%$ by 2020 and roughly $45 \%$ by 2030 .

In 2009, the piloted PFES schemes were initially introduced in Son La province and Lam Dong province where deforestation and forest degradation were regarded as the most serious in Vietnam at that time. Next, Decree No. 99 in 2010 mandated the implementation of PFES nationwide even though the PES mechanism is quite different from the PES definition of Wunder (2005) because (1) ES buyers and sellers are selected instead of volunteering to participate, (2) the authorities have right to establish the levels of payments relied heavily on the specific types of forest ecosystem services (i.e. biodiversity loss, carbon sequestration, afforestation and watershed protection). In most cases, forest owners sign a civil contract (also called as the forest protection contract) with local peasant farmers who have so much experience in taking care of and protecting forest and often took part in the national forest programs (i.e. Program 661 and Program 327) in the past. Nearly 11000 contracts have been signed up till now, and more importantly, more and more local households want to participate the PFES scheme if any. The Forest Protection and Development Fund has responsibility for collecting payments from ES buyers, then re-distribute them forest owners, who in turn pay local peasant farmers once at a specific periotic time, often every quarter.

To date, more than 20 PFES programs have been implemented nationwide through a civil contract drafted by the government so far. The terms in every PFES contract oblige private and state agencies to finance to forest owners for protection and development of forest and inversely forest ecosystem services suppliers (forest owners) will be punished in case of non-compliance. The progressive enhancement of legal frameworks regarding the implementation of PFES is clear illustration for the government's interest and commitment to achieving effective, efficient and equitable outcomes from PFES schemes (Pham et al., 2013). 
Figure 1. Roles and responsibilities of ecosystem service providers and buyers

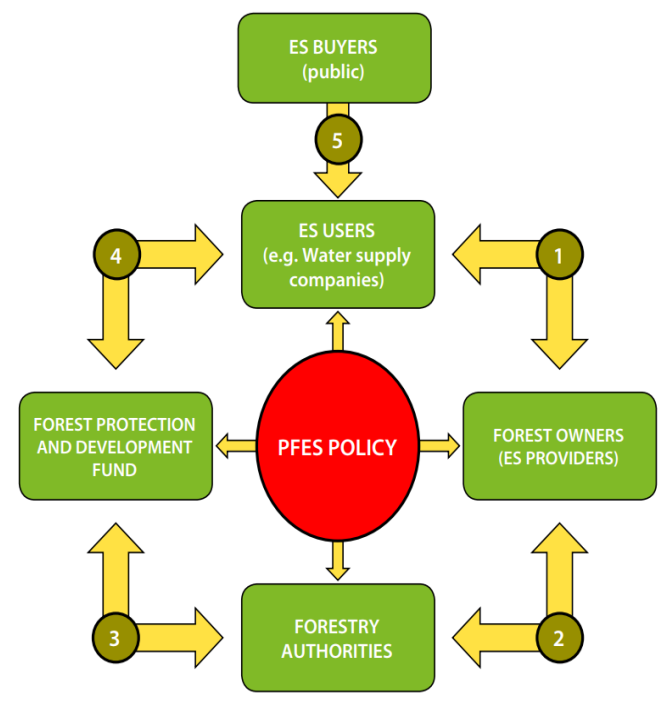

1. Relationship between environmental services (ES) buyers/users and sellers/providers (applies to direct payment agreements).

2. Traditional relationship for control and management of forest quantity and quality outside PFES scheme.

3. Relationship in monitoring and evaluation by checking randomly $10 \%$ of the forest area under PFES scheme.

4. Relationship in signing contracts for PFES (applies to agreements for indirect payments).

5. The PFES scheme covered by Decree 99 establishes a fixed payment rate for hydropower plants and water supply and tourism companies (20 VND (around 1 cent) for $1 \mathrm{kWh}, 40$ VND for $1 \mathrm{~m} 3$ of clean water, $1-2 \%$ of revenues, respectively), but payments may be included in the price of electricity and clean water and any entrance fees.

Source: Adapted by Pham et al. (2013)

\section{Methods}

\section{Study site}

The study region is located in Quang Nam province of Vietnam, where the PFES project has been implementing across 13 forested districts since 2012 under Decree No. 99, and focused on four categories of PFES, including (1) watershed protection, namely soil protection, reduction in land erosion, prevention of sedimentation of rivers, streams and reservoirs; (2) protection of natural landscapes and biodiversity conservation for developing tourism; (3) carbon sequestration, reduction in greenhouse gas emission by preventing forest resources from deforestation and degradation; and (4) provision of natural seeds and feeds as well as sources of water for the aquaculture sector. Presently, beneficiaries or ES buyers are hydropower plants, fresh water supply firms, tourism company while ES sellers are forest owners including forest management boards, stateowned forest enterprises, private company, and so many households.

Nowadays, more than half of Quang Nam is covered by forests, in which the high percentage of forest are natural forests with some many species of extinction-risk and precious flora and fauna. Quang Nam province is also the place where the vast majority of indigenous residents still earn their living under the forestry sector. Quang Nam is also home to the conservation parks of the saola (Pseudoryx nghetinhensis), the redshanked douc (Pygathrix nemaeus), the Song Thanh protected area and the Cu Lao Cham Biosphere reserves. The forests in Quang Nam now contains the sheer richness of biodiversity with respect to genes, individual species, communities of creatures, and entire ecosystems, however are also highly been threating by climate change as well as deforestation and forest degradation (Pham et al., 2013). 
In present, a large proportion of total natural area is considered as "forest land", whereas there is the shortage of production land for planting activities and animal husbandry, leading to substantial reduction in the living standards of mountainous people. Thus, current conservation policies like PFES can support and encourage forest conservation and economic development in private lands as well as protection of natural resources.

Figure 2. The location and map of Quang Nam province, Vietnam

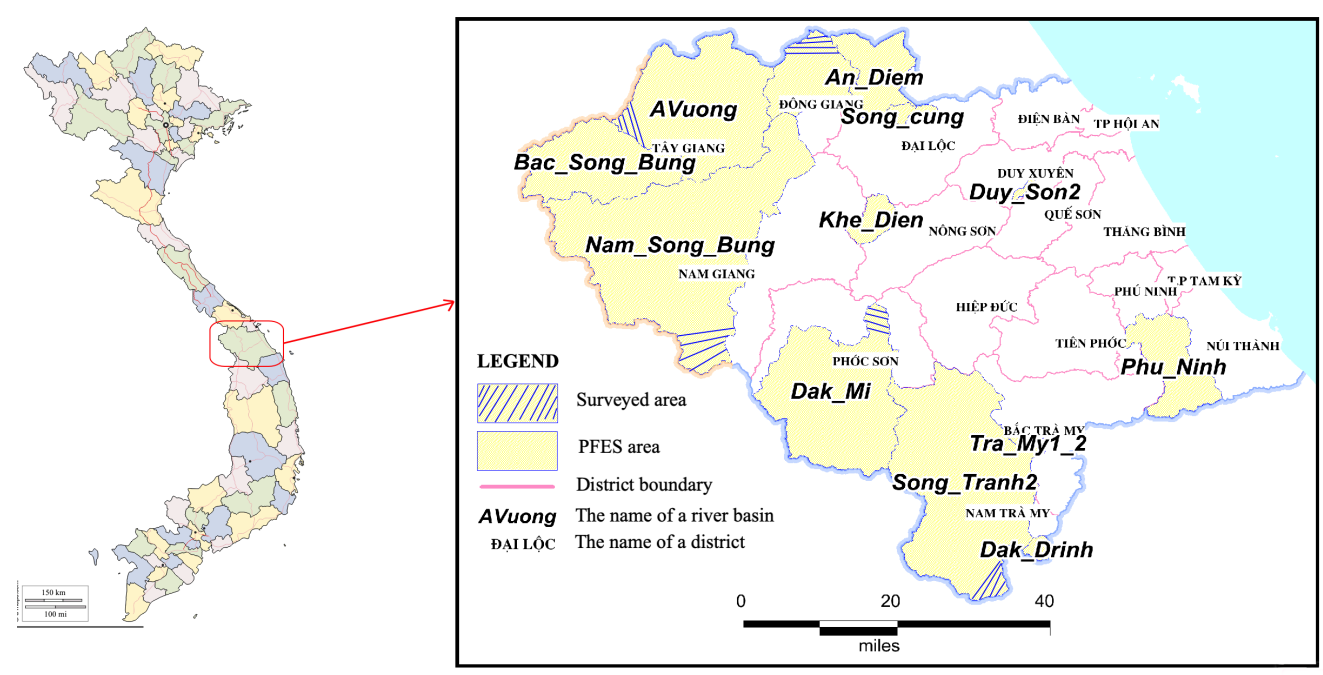

Source: Quang Nam Provincial Forest Protection Department (2019)

Currently, according to the latest report from the Quang Nam Provincial Forest Protection Department (2019), total PFES area is coral reefs 276,826 ha across 31 river basins of 13 forested districts of Quang Nam with total payments in 2019 of 4,662,531 US dollar (roughly $17 \%$ increase in payments compared to that of 2018).

\section{Sampling and survey methods}

PES-participants and nonparticipants were selected randomly in 4 districts of Quang Nam province, specifically sampling procedure mainly based on demographic and socio-economic characteristic information provided by the local forest management boards. There were two different forms of the questionnaire used to survey, one for PES-participants and the other for nomparticipants. For PES-participants, this study was designed as a cross - sectional investigation, in which 323 households were randomly sampled by the cluster sampling scheme from July 2018 to March 2019, while 146 nonparticipants were interviewed at the same time. To ensure the robustness of estimated results, our survey only included (1) respondents with the age of 18-60, (2) respondents taking part in both agriculture and agroforestry activities, (3) a balance share between Kinh people and ethnic groups. Every interview lasted from 60 to 120 minutes. 
Every questionnaire for PES-participants and nonparticipants comprised of five parts, in which the questions were very straightforward and mainly involved household socio-demographic characteristics, revenue streams and cost from agriculture and agroforestry before and after the implementation of the PFES project, household attitudes towards economic impact of PFES. The households for the survey came from four districts, including Hiep Duc, Phu Ninh, Dai Loc and Tien Phuoc. The sociodemographic characteristics of surveyed households in the sample were summarized in Table 2 .

Table 2. The social-demographic characteristics of respondents

\begin{tabular}{|c|c|c|c|c|}
\hline & Hiep Duc & Phu Ninh & Dai Loc & Tien Phuoc \\
\hline Total respondents & 155 & 102 & 132 & 80 \\
\hline \multicolumn{5}{|l|}{ Gender } \\
\hline Female & 18 & 10 & 16 & 8 \\
\hline Male & 137 & 92 & 116 & 72 \\
\hline Control groups & 46 & 22 & 50 & 28 \\
\hline Treated groups & 109 & 80 & 82 & 52 \\
\hline \multicolumn{5}{|l|}{ Ethnic groups } \\
\hline Kinh & 54 & 25 & 40 & 30 \\
\hline Minority & 101 & 77 & 92 & 50 \\
\hline \multicolumn{5}{|l|}{ Main crop } \\
\hline Maize & 49 & 57 & 59 & 18 \\
\hline Other crops & 106 & 45 & 73 & 62 \\
\hline Age of respondents (years) & 41.30 & 40.46 & 39.52 & 41.19 \\
\hline Year of schooling & 6.59 & 7.35 & 7.54 & 6.83 \\
\hline Total members in the household & 4.74 & 4.80 & 5.05 & 4.81 \\
\hline Working members & 2.63 & 2.64 & 2.72 & 2.73 \\
\hline Members under the age of 15 & 2.08 & 2.17 & 2.10 & 1.81 \\
\hline Total income (\$) & 4480.39 & 3573.26 & 4520.82 & 4969.87 \\
\hline Income from forest activities $(\$)$ & 406.45 & 456.39 & 358.39 & 375.60 \\
\hline Income from agricultural activities $(\$)$ & 3376.62 & 2289.28 & 3313.82 & 3402.76 \\
\hline Income from hired labor $(\$)$ & 452.54 & 680.32 & 650.99 & 661.74 \\
\hline
\end{tabular}

Source: The calculation from the authors

\section{Data validation}

To detect fallacy and ensure data accuracy and reliability, we used the solutions as follow: (2) the survey questionnaire was well-designed, pre-tested and improved before the official survey; (1) the chosen respondents were initially approached by phone with the help of the local authorities, in case they agreed to join the survey, questionnaires would be finished through direct interviews; (3) interviewers were taken part in several 
courses in terms of interview skills training before the fieldwork; (4) outlier data and responses with significant errors were eliminated from the analysis; (5) interview procedure was scrupulously organized and controlled by the team leader; finally, the finished questionnaires were coded, imported in STATA, then double-check prior to official analysis.

\section{Propensity Score Matching}

As a rule, the local authorities will select participants in the PFES projects on purpose, meaning that participation is, certainly, not stochastics, thus this study used a statistical matching technique called Propensity Score Matching (PSM) to measure the PFES scheme's impact by the Average Treatment Effect on Treated (ATET). Propensity scores (PS) are known as the estimated probability of the treatment by accounting for the covariates that predict receiving the treatment and in this research, PS will be estimated by an probit regression model (Ramsey, Forsyth, Wright, McKay, \& Westbrooke, 2019) with the help of STATA 14. Through a treatment effect model, the research compared the average potential outcome of interest between treated and controlled groups to assess the intervention actions' effectiveness.

Let $E\left[Y_{1} \mid D=1\right]$ be the average potential outcomes (i.e. income) for the treated group (participants), and $\mathrm{E}\left[\mathrm{Y}_{0} \mid \mathrm{D}=1\right]$ be the average potential outcome for the controlled group (nonparticipants). Then, ATET could be calculated as follow (Słoczyński \& Wooldridge, 2018):

$$
\begin{gathered}
\mathrm{ATET}=\mathrm{E}\left[\mathrm{Y}_{1} \mid \mathrm{D}=1\right]-\mathrm{E}\left[\mathrm{Y}_{0} \mid \mathrm{D}=1\right] \\
\mathrm{ATET}=\mathrm{E}\left[\mathrm{Y}_{1}-\mathrm{Y}_{0} \mid \mathrm{D}=1\right]
\end{gathered}
$$

In the above formula, $E\left[Y_{1}-Y_{0} \mid D=1\right]$ represents the effectiveness of PFES. $Y_{1}$ and $\mathrm{Y}_{0}$ are overall income of PES-participants and nonparticipants, respectively. The term $D$ is a dummy variable as the treatment indicator which equals one if the surveyed household is in the PFES group and zero if otherwise.

However, the challenge was that we could not observe the outcomes of a household participated in PFES $(\mathrm{D}=1)$, but presently no longer participates anymore $\left(\mathrm{Y}_{0} \mid \mathrm{D}=\right.$ 1). To deal with this challenge, we created a counterfactual variable from group of nonparticipants in the sample, then simply replaced $\left(\mathrm{Y}_{0} \mid \mathrm{D}=1\right)$ by $\left(\mathrm{Y}_{0} \mid \mathrm{D}=0\right)$. Thus, ATET is simply estimated as $A T E T=E\left[Y_{1} \mid D=1\right]-E\left[Y_{0} \mid D=0\right]$ (Guo \& Fraser, 2015). Additionally, to improve the ATET to be appropriate for calculation of the treatment effect, the research mimicked the conditions for a randomized experiment satisfying the equation $\mathrm{Y}_{0}, \mathrm{Y}_{1} \wedge \mathrm{D} \backslash \mathrm{X}$, where $\mathrm{X}$ represented the covariates influencing to selection and the estimator outcome.

Furthermore, the study also used the difference-differences (DID) method to enhance the robustness of the matching procedure and to decrease the bias when the treated and controlled group are systematically different from each other. This approach computed the effect of an intervention on a specific outcome by comparing the average change of 
the outcome variable for the treated and controlled groups over time. The DID estimator is defined as:

$$
\begin{gathered}
\mathrm{DID}=\mathrm{E}\left[\mathrm{Y}_{\mathrm{n}}-\mathrm{Y}_{\mathrm{m}} \mid \mathrm{D}=1\right]-\mathrm{E}\left[\mathrm{Y}_{\mathrm{n}}-\mathrm{Y}_{\mathrm{m}} \mid \mathrm{D}=0\right] \\
\mathrm{DID}=\mathrm{E}[\Delta \mathrm{Y} \mid \mathrm{D}=1]-\mathrm{E}[\Delta \mathrm{Y} \mid \mathrm{D}=0]
\end{gathered}
$$

In the above formula, $\mathrm{n}$ and $\mathrm{m}$ represent "before" and "after" the implementation of PFES, and hence $\triangle \mathrm{Y}$ stands for the change in outcomes "before" and "after" the PFES is introduced in the study site.

\section{Gini index}

To assess the effectiveness of the PFES project, the paper computed the change in income inequality of a population by using Gini coefficient whose formula was proposed by Yitzhaki (1994) as follow:

$$
G=\frac{2 \operatorname{Covar}\left(y, r_{y}\right)}{N \bar{y}}
$$

where $\mathrm{G}$ denotes Gini index, $\operatorname{Covar}\left(\mathrm{y}, \mathrm{r}_{\mathrm{y}}\right)$ is the covariance between income (y) and the ranks of all households in the sample according to their income $\left(r_{y}\right)$ which ranges from the poorest household $(\operatorname{rank}=1)$ to the richest $(\operatorname{rank}=\mathrm{N})$. $\mathrm{N}$ is total number of observations and $\bar{y}$ represents mean income of the survey sample. The Gini coefficient will vary from 0 to 1 , with 0 expressing perfect equality (meaning that every household has the same income level) and 1 representing perfect inequality (implying that only one household has all the income while remaining others have none).

\section{Results and discussion}

\section{Probit model}

With the aim of measuring propensity scores of the PFES scheme, the probit regression model was estimated with the explained variable as a dummy variable (1 if PES-participant and 0 otherwise). The independent variables included the surveyed households' social demographic characteristics: (1) The dummy for the main crop, (2) the dummy for years of settlement, (3) the dummy for ethnic groups, (4) ages of head of households, (5) average distance to forest, (6) pre-PES income, (7) income from agricultural activities, (8) years of schooling of respondents. 
Table 3. Estimation results of the probit model for selection into the PFES scheme

\begin{tabular}{|c|c|c|c|c|c|c|c|}
\hline & Coef. & St.Err. & t-value & p-value & {$[95 \%$ Conf } & Interval] & Sig. \\
\hline $\begin{array}{l}\text { Dummy for main crop } \\
\text { (=1 if rubber) }\end{array}$ & -0.402 & 0.165 & -2.44 & 0.015 & -0.724 & -0.079 & $* *$ \\
\hline $\begin{array}{l}\text { Dummy for years of } \\
\text { settlement ( }=1 \text { if }>=20 \\
\text { years) }\end{array}$ & 0.831 & 0.252 & 3.30 & 0.001 & 0.338 & 1.325 & $* * *$ \\
\hline $\begin{array}{l}\text { Dummy for ethnic groups } \\
\text { (=1 if Kinh) }\end{array}$ & 0.654 & 0.197 & 3.33 & 0.001 & 0.269 & 1.040 & $* * *$ \\
\hline Age (years) & -0.022 & 0.006 & -3.47 & 0.001 & -0.034 & -0.009 & $* * *$ \\
\hline $\begin{array}{l}\text { Average distance to forest } \\
(\mathrm{km})\end{array}$ & -0.019 & 0.005 & -3.51 & 0.000 & -0.030 & -0.008 & $* * *$ \\
\hline PrePES income (\$) & -0.0001177 & 0.0000186 & -6.32 & 0.000 & \begin{tabular}{ll|}
-0.0001542 \\
\end{tabular} & -0.0000811 & $* * *$ \\
\hline Agricultural income (\$) & $\begin{array}{r}0.290 \\
\end{array}$ & 0.076 & 3.79 & 0.000 & 0.140 & 0.440 & $* * *$ \\
\hline Years of schooling & 0.037 & 0.020 & 1.89 & 0.059 & -0.001 & 0.075 & $*$ \\
\hline Constant & 0.699 & 0.348 & 2.01 & 0.045 & 0.016 & 1.382 & $* *$ \\
\hline \multicolumn{2}{|l|}{ Mean dependent var } & 0.689 & \multicolumn{3}{|c|}{ SD dependent var } & \multicolumn{2}{|c|}{0.464} \\
\hline \multicolumn{2}{|l|}{ Pseudo r-squared } & 0.157 & \multicolumn{3}{|c|}{ Number of obs } & \multicolumn{2}{|c|}{469.000} \\
\hline \multicolumn{2}{|l|}{ Chi-square } & 91.338 & \multicolumn{3}{|c|}{ Prob $>$ chi2 } & \multicolumn{2}{|c|}{0.000} \\
\hline \multicolumn{2}{|l|}{ Akaike crit. (AIC) } & 508.351 & \multicolumn{3}{|c|}{ Bayesian crit. (BIC) } & \multicolumn{2}{|c|}{545.706} \\
\hline$* * * p<0.01, * * p<0.05, *$ & & & & & & & \\
\hline
\end{tabular}

Source: The calculation from the authors

The estimation results in Table 3 showed that the probit model was statistically significant because Chi-square equaled 91.338 and Prob $>$ Chi-square equaled 0.000. Furthermore, the explanatory variables in the model had a sig. $<5 \%$, suggesting that they actually affected the PFES participation of households although the effect size was either positive or negative. The families planting rubber as the main crop was found to be less likely to take part in the PFES project, probably because the current PFES resulted in higher opportunity cost and fairly low payment rate, thereby decline total income of the household. This finding was in agreement with our prior expectation. Likewise, older people had the lower probability in PFES participation than younger people and the distance to forest discouraged the households participate the PFES program. The negative relationship between the pre-PFES income level and the likelihood of PFES argued that the households with the high pre-PFES income level did not tend to join the PFES because they were not motivated to get additional income from PFES program. This exploration was in line with the research of Wang et al. (2019) and Watson et al. (2018).

\section{Treatment effects by propensity scores matching}

The summary of the estimation results of the ATET by PSM regarding the difference in the total income in 2019 and DID was displayed in Table 4. With reference to analyzing results, Average Treatment Effect (ATE) was also estimated and showed in Table 4. In the matching procedure, ATET and ATE were estimated to prioritize the requirement of overlap assumption by calculating the kernel density of the predicted propensity scores 
for PES-participants and nonparticipants. Figure 3 displayed a clear image that the plot showed little estimated probability mass near 0 or 1 , and the two estimated densities had most of their respective masses in region of common support, thus, confirmed that the requirement of overlap assumption was met (Clements \& Milner-Gulland, 2015; Leite, Aydin, \& Gurel, 2019).

Table 4 demonstrated that the unmatched difference in the total income in 2019 between PESparticipants and nonparticipants was minus 857.807 US dollar and statistically significant $(\mid$ T-stat $\mid>1.96)$ while both ATET and ATE were not statistically significant $(\mid$ T-stat $\mid<1.96)$, meaning that the implementation of PFES schemes did not lead to change of total income of participants under cross-sectional data. This finding was rather consistent with the results of Wang et al. (2019) and Hanauer and Canavire-Bacarreza (2015).

Table 4. Estimation results of ATET with PMS

\begin{tabular}{|l|c|r|r|r|r|r|}
\hline \multicolumn{2}{|c|}{} & Treated & Controls & Coef. & St.Err. & T-stat \\
\hline \multirow{3}{*}{$\begin{array}{l}\text { Cross-sectional } \\
(2019)\end{array}$} & Unmatched & 110.941 & 968.748 & -857.807 & 393.821 & -2.180 \\
\cline { 2 - 7 } & ATET & 4110.941 & 4238.390 & -127.449 & 714.134 & -0.180 \\
\cline { 2 - 7 } & ATE & - & - & 262.442 & 320.117 & 0.82 \\
\hline \multirow{2}{*}{$\begin{array}{l}\text { DID estimators } \\
(2010-2019)\end{array}$} & Anmatched & 1212.942 & -61.626 & 1274.569 & 250.388 & 5.090 \\
\cline { 2 - 7 } & ATET & 1212.942 & 328.917 & 884.025 & 556.060 & 1.590 \\
\cline { 2 - 7 } & & - & - & 765.55 & 191.6678 & 3.99 \\
\hline
\end{tabular}

Source: The calculation from the authors

As mentioned previously, the DID estimator, which bases on the longitudinal data (20102019), provides the more robust estimates of treated effect of intervention actions. The most advantage of DID estimator is to control systematic differences in the household characteristics between the treated and controlled groups. As displayed in Table 4, the unmatched difference was positive (1274.569 US dollar) and highly significant while ATET and ATE estimators were 884.025 US dollar and 765.55 US dollar respectively with statistically significance of the $5 \%$ and $1 \%$ level. This finding pointed to the positive change in total income of participants, compared to that of nonparticipants and also collaborated the effectiveness of the PFES scheme in the long-term. 
Figure 3. The distribution of estimated propensity scores

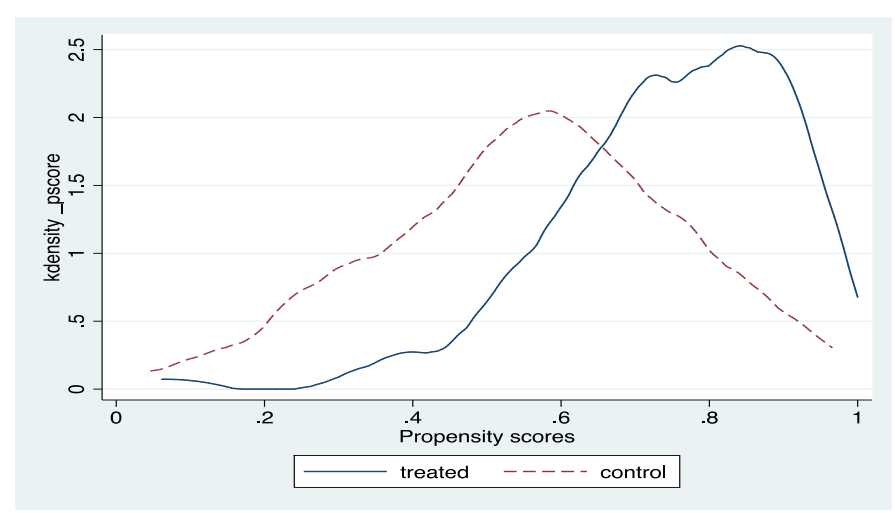

Source: The calculation from the authors

\section{The change in income inequality}

To analyze the change in income inequality and the distribution of income between the treated and controlled groups, this study computed the Gini index in 2010 and 2019. As can be seen in Table 5, the 2019 income distribution was more equal for PES-participants $(\mathrm{Gini}=0.381)$ than nonparticipants $(\mathrm{Gini}=0.413)$. The research of J. Li, Feldman, Li, and Daily (2011) in terms of the largest PES projects in China also displayed the same finding.

Before the introduction of PFES, Gini index for PES-participants and nonparticipants were 0.471 and 0.436 respectively, suggesting that the income distribution among PESparticipants was more unequal than nonparticipants. However, this situation has varied substantially after seven years of PFES implementation. For the change in income inequality before and after the PFES introduction, Table 5 argued the $19.11 \%$ and $5.28 \%$ decline for PES-participants and nonparticipants, respectively. For whole sample, the results illustrated the nearly $18 \%$ decrease in income inequality (from 0.484 to 0.399 ). This finding confirmed the effectiveness of PFES in terms of the reduction in income inequality.

Table 5. The change in income inequality during period 2010-2019

\begin{tabular}{|c|c|c|c|c|c|c|}
\hline & Gini & Std.Err. & $\mathrm{t}$ & $\mathrm{P}>\mathrm{t}$ & [95\%Conf. & Interval] \\
\hline \multicolumn{7}{|c|}{ Total income in 2019} \\
\hline PES participants & 0.381 & 0.024 & 16.05 & 0.000 & 0.334 & 0.427 \\
\hline Nonparticipants & 0.413 & 0.0196 & 21.07 & 0.000 & 0.375 & 0.452 \\
\hline Whole sample & 0.399 & 0.016 & 24.970 & 0.000 & 0.368 & 0.430 \\
\hline \multicolumn{7}{|c|}{ Total income in 2010} \\
\hline PES participants & 0.471 & 0.035 & 13.55 & 0.000 & 0.403 & 0.5396 \\
\hline Nonparticipants & 0.436 & 0.020 & 21.74 & 0.000 & 0.397 & 0.476 \\
\hline Whole sample & 0.484 & 0.020 & 24.440 & 0.000 & 0.445 & 0.522 \\
\hline
\end{tabular}

Source: The calculation from the authors 


\section{Conclusion, recommendations and limitations}

\section{Conclusion}

Nowadays, the PES projects are been implementing across the world with the aim of improving both natural resources and mountainous community. As a consequence, so many PES-related researches have been conducting and rising attention from academics, practitioners and policymakers with the expanding scope in theory and practice. Along with this trend, the Vietnamese government have been mandating the local authorities to carry out the PFES scheme across the country since 2008 under Decision No. 380, yet the effectiveness of PFES implementation have been questioned and not many experimental studies evaluate the PFES effectiveness, especially in the context of tropical forests in Vietnam. So, the overall purpose of this paper was to explore and measure the effectiveness of the PFES scheme in Vietnam by using the propensity scores analysis which have not yet conducted in Vietnam before. To achieve the research objectives, the study randomly surveyed 469 households living in four districts across Quang Nam province of Vietnam by the questionnaire and used propensity scores to estimate the PFES program's effectiveness through ATET. In addition, to enhance the robustness of the matching procedure and decline the bias when the treated and controlled group differed systematically, the study also utilized DID approach to measure the change in the household income before and after the introduction of PFES. Several conclusions were summarized as follows:

With the cross-sectional data in 2019, the estimated results by the analysis of propensity scores demonstrated that the difference in total household income within and without PFES was found to be not statistically significant. This implied that PFES scheme did not affect the household income and no evidence to support the effectiveness of PFFES. Arriagada et al. (2015) explain that the main reason of this situation was considerable cost of PFES participation and contract compliance. The other quite important reason was that ineffective management of PFES projects in the developing countries limited livelihood opportunities for indigenous community (Clements \& Milner $\square$ Gulland, 2015), thereby restricted to develop the types of crops and resulted in farmland abandonment (Clements, Suon, Wilkie, \& Milner-Gulland, 2014). Conversely, the PES policy might provide so many important kinds of forest resources (i.e. resin, animals, wood) for beneficiaries who did not obey PES contracts (Clements et al., 2014).

However, the results from DID estimators showed that ATET and ATE were positive and statistically significant with $5 \%$ and $1 \%$ level, implying that PFES resulted in the higher income for participants. The difference in household income participants and nonparticipants were 884.025 US dollar and 765.55 US dollar, respectively. This conclusion is quite consistent with the report of Sharma, Cho, and Yu (2019).

In terms of the change in income inequality, the Gini coefficient illustrated the positive and substantial progress for reduction in income inequality after the implementation of PFES. In detail, the current income distribution was more equal for PES-participants $(\mathrm{Gini}=0.381)$ than nonparticipants $(\mathrm{Gini}=0.413)$. Additionally, the $19.11 \%$ and $5.28 \%$ 
decline in income inequality for PES-participants and nonparticipants respectively resulted from the introduction of PFES. This conclusion was so relevant to the effectiveness of the PFES policy in Vietnam. The study of Q. Li and Zander (2019) and Treacy et al. (2018) also illustrated the same finding.

\section{Recommendations}

Based on the above results, for the purpose of improving the PFES effectiveness in the future, some recommendations for the PFES design may be proposed as follow:

Firstly, the first priority of design of the PFES project is the improvement of income and livelihood for mountainous community, especially for poor community and ethnic groups. This suggestion is also in agreement with arguments from previous literature, for example Treacy et al. (2018), Ito, Feuer, Kitano, and Asahi (2019), Ezzine-deBlas, Corbera, and Lapeyre (2019) and Bremer et al. (2019). Kanchanaroek and Aslam (2018) argue that success and sustainability of any intervention policy like PFES will mainly rely on the participants' satisfaction. This survey results displayed the quite low average payment for participants, was just nearly $17 \$$ per hectare, thus hardly meet fully for daily expenses of households as well as for production activities. Further, with such a low amount of payments, PES-participants will not be encouraged to protect allocated forests effectively.

Secondly, the direct payment should be replaced by a loan fund at the village level which is controlled and supervised by local community with the consultation of authorities. According to Costedoat (2017), this solution is able to help creditors use loan money on their expenses and production the most effectively.

Next, forest protection activities should be encouraged for participants to be paid the more income because so many households (roughly 15\%) in the study region had capability to labor in agricultural sector but lack of land to plant crops leaded to decrease in agricultural productivity. This was demonstrated to be an efficient implication for designing PFES programs in the world (Austin, Schwantes, Gu, \& Kasibhatla, 2019; Bremer et al., 2019; Steger et al., 2018). Besides, it is so important to support farmers in advancing agricultural extension skills, such as cultivation techniques, market information, and post-harvest product protection).

Finally, it is so essential to establish a monitoring mechanism to hinder non-compliance with the regulations.

\section{Limitations}

Firsly, it's worth noting that households are currently simultaneously receiving money from the different sources of subsidies, such as Program 661 (known as the Five Million Hectare Reforestation Program) and Program 30A (known as the Speedy and Sustainable Poverty Reduction Program for the 61 Poorest Districts). Thus, the effectiveness of intervention policy on community might be determined by the interaction of these 
above programs rather than only the PFES scheme. As a result, to measure the separate impact of PFES program on each potential outcome is so hard. Hence, we strongly suggest that the further research need to separate the actual influence of the intervention actions for the purpose of estimating the real effectiveness of the PFES program on targeted groups.

Next, keep in mind that data for calculating ATE and ATET was collected from recalled information of respondents in the past, which is so difficult to testify due to the shortage of official records regarding household income and production activities. So, this leads to the magnitude of potential instability, unreliability and bias. Therefore, the further research should use both self-reported information and official records of authorities to ensure the accuracy of analysis. This recommendation is also discussed fairly carefully by López-Pintor, Salas, and Rescia (2018)

Last but not least, because this study was conducted in only one province implementing the PFES regime, thus it must be remembered that the analyzed data from the survey was full of representativeness for the study site while the estimation results was difficult to be applied for another study region due to the fact that there is the such considerable heterogeneity with respect to socio-economic characteristics of respondents and conditions for applied PFES activities. Therefore, more studies in the other areas with alternative methods should be conducted to confirm the results of this study for better policies.

\section{Acknowledgements}

The authors would like to thank colleagues for very thoughtful reviews and critical comments, which have led to significant improvements to the early versions of the manuscript.

\section{Conflict of interests}

The authors declare no conflict of interest.

\section{References}

1. Alix-Garcia, J., McIntosh, C., Sims, K. R., \& Welch, J. R. (2013). The ecological footprint of poverty alleviation: evidence from Mexico's Oportunidades program. Review of Economics and Statistics, 95(2), 417-435. doi:https://doi.org/10.1162/ $\underline{\text { REST a } 00349}$

2. Arriagada, R. A., Sills, E. O., Ferraro, P. J., \& Pattanayak, S. K. (2015). Do payments pay off? Evidence from participation in Costa Rica's PES program. PloS one, 10(7), e0131544. doi:https://doi.org/10.1371/journal.pone.0131544

3. Asian Development Bank. (2014). Scaling up payments for forest environmental services in Viet Nam: Lessons and insights from Quang Nam (Vol. 1). Philippines: Metro Manila. 
4. Austin, K. G., Schwantes, A., Gu, Y., \& Kasibhatla, P. S. (2019). What causes deforestation in Indonesia? Environmental Research Letters, 14(2), 024007. doi:https://doi.org/10.1088/1748-9326/aaf6db

5. Beauchamp, E., Clements, T., \& Milner-Gulland, E. (2018). Assessing mediumterm impacts of conservation interventions on local livelihoods in Northern Cambodia. World Development, 101, 202-218. doi:https://doi.org/10.1016/j. worlddev.2017.08.008

6. Birte Snilstveit, Jennifer Stevenson, Laurenz Langer, Natalie Tannous, Zafeer Ravat, Promise Nduku, . . . Ferraro, P. J. (2019). Incentives for climate mitigation in the land use sector-the effects of payment for environmental services (PES) on environmental and socio-economic outcomes in low-and middle-income countries (M. Gaarder Ed.). 3ie Systematic Review 44. London: International Initiative for Impact Evaluation (3ie).

7. Bremer, L. L., Wada, C. A., Medoff, S., Page, J., Falinski, K., \& Burnett, K. (2019). Assessing the contribution of multi-benefit native forest protection to local water supplies: A case study from East Maui, Hawai'i. Science of The Total Environment. doi:https://doi.org/10.1016/j.scitotenv.2019.06.220

8. Clements, T., \& Milner-Gulland, E. (2015). Impact of payments for environmental services and protected areas on local livelihoods and forest conservation in northern Cambodia. Conservation biology, 29(1), 78-87. doi:https://doi.org/10.1111/ cobi. 12423

9. Clements, T., Suon, S., Wilkie, D. S., \& Milner-Gulland, E. (2014). Impacts of protected areas on local livelihoods in Cambodia. World Development, 64, S125-S134. doi:https://doi.org/10.1016/j.worlddev.2014.03.008

10. Costedoat, S. (2017). Assessing the effectiveness of payments for environmental services in improving community-based forest conservation in Chiapas, Mexico. (Doctor of philosophy), Autonomous University of Barcelona, Retrieved from https://hdl.handle.net/10803/457435

11. Do, T. H., Vu, T. P., \& Catacutan, D. (2018). Payment for forest environmental services in Vietnam: An analysis of buyers' perspectives and willingness. Ecosystem Services, 32, 134-143. doi:https://doi.org/10.1016/j.ecoser.2018.07.005

12. Ezzine-de-Blas, D., Corbera, E., \& Lapeyre, R. (2019). Payments for environmental services and motivation crowding: Towards a conceptual framework. Ecological economics, 156, 434-443. doi:https://doi.org/10.1016/j.ecolecon.2018.07.026

13. Guo, S., \& Fraser, M. W. (2015). Propensity score analysis. the United States of America: Sage.

14. Hanauer, M. M., \& Canavire-Bacarreza, G. (2015). Implications of heterogeneous impacts of protected areas on deforestation and poverty. Philosophical Transactions of the Royal Society B: Biological Sciences, 370(1681), 20140272. doi: https://doi. org/10.1098/rstb.2014.0272 
15. Ito, J., Feuer, H. N., Kitano, S., \& Asahi, H. (2019). Assessing the effectiveness of Japan's community-based direct payment scheme for hilly and mountainous areas. Ecological economics, 160, 62-75. doi:https://doi.org/10.1016/j. ecolecon.2019.01.036

16. Jespersen, K., \& Gallemore, C. (2018). The institutional work of payments for ecosystem services: why the mundane should matter. Ecological economics, 146, 507-519. doi:https://doi.org/10.1016/j.ecolecon.2017.12.013

17. Kanchanaroek, Y., \& Aslam, U. (2018). Policy schemes for the transition to sustainable agriculture-Farmer preferences and spatial heterogeneity in northern Thailand. Land use policy, 78, 227-235. doi:https://doi.org/10.1016/j. $\underline{\text { landusepol.2018.05.026 }}$

18. Leite, W. L., Aydin, B., \& Gurel, S. (2019). A Comparison of Propensity Score Weighting Methods for Evaluating the Effects of Programs With Multiple Versions. The Journal of Experimental Education, 87(1), 75-88. doi:https://doi.org/10.1080/ $\underline{00220973.2017 .1409179}$

19. Li, J., Feldman, M. W., Li, S., \& Daily, G. C. (2011). Rural household income and inequality under the Sloping Land Conversion Program in western China. Proceedings of the National Academy of Sciences, 108(19), 7721-7726.

20. 20. Li, Q., \& Zander, P. (2019). Resilience building of rural livelihoods in PES programmes: A case study in China's Loess Hills. Ambio, 1-24. doi:https://doi. org/10.1007/s13280-019-01236-4

21. López-Pintor, A., Salas, E., \& Rescia, A. (2018). Assessment of Agri-Environmental Externalities in Spanish Socio-Ecological Landscapes of Olive Groves. Sustainability, 10(8), 2640. doi:https://doi.org/10.3390/su10082640

22. Manjula, M., Venkatachalam, L., Mukhopadhyay, P., \& Kumar, L. (2019). Ecosystem services approach for revitalizing agriculture in India. CURRENT SCIENCE, 116(5), 723. Retrieved from https://www.currentscience.ac.in/Volumes/116/05/0723.pdf.

23. Muttaqin, M. Z., Alviya, I., Lugina, M., \& Hamdani, F. A. U. (2019). Developing community-based forest ecosystem service management to reduce emissions from deforestation and forest degradation. Forest Policy and Economics, 101938. doi:https://doi.org/10.1016/j.forpol.2019.05.024

24. Pauline, N. K. (2016). Payments for forest environmental services in sub-Saharan Africa - A practical guide (B. Foday, M. Rao, H. Barbara, \& N. Bernardete Eds. Vol. 1): FAO, New York City.

25. Pham, T. T., Bennett, K., Vu, T. P., Brunner, J., Le Ngoc, D., \& Nguyen, D. T. (2013). Payments for forest environmental services in Vietnam: from policy to practice. CIFOR Occasional Paper(93). Retrieved from http://www.cifor.org/.../ OP-93.pdf.

26. Quang Nam Provincial Forest Protection Department. (2019). The payments for forest ecoystem services during 2018-2019. Retrieved from Quang Nam: 
27. Ramsey, D. S., Forsyth, D. M., Wright, E., McKay, M., \& Westbrooke, I. (2019). Using propensity scores for causal inference in ecology: Options, considerations, and a case study. Methods in Ecology and Evolution, 10(3), 320-331. doi:https:// doi.org/10.1111/2041-210X.13111

28. Ruggiero, P. G., Metzger, J. P., Tambosi, L. R., \& Nichols, E. (2019). Payment for ecosystem services programs in the Brazilian Atlantic Forest: Effective but not enough. Land use policy, 82, 283-291. doi:https://doi.org/10.1016/j. landusepol.2018.11.054

29. Samii, C., Lisiecki, M., Kulkarni, P., Paler, L., \& Chavis, L. (2014). Effects of payment for environmental services (PES) on deforestation and poverty in low and middle income countries: a systematic review. Campbell Systematic Reviews, 10(11), 95. doi:10.4073/csr.2014.11

30. Sharma, B. P., Cho, S.-H., \& Yu, T. E. (2019). Designing cost-efficient payments for forest-based carbon sequestration: An auction-based modeling approach. Forest Policy and Economics, 104, 182-194. doi:https://doi.org/10.1016/j. forpol.2019.04.018

31. Słoczyński, T., \& Wooldridge, J.M.(2018).A GENERALDOUBLE ROBUSTNESS RESULT FOR ESTIMATING AVERAGE TREATMENT EFFECTS. Econometric Theory, 34(1), 112-133. Retrieved from https://www.cambridge.org/core/article/ general-double-robustness-result-for-estimating-average-treatment-effects/ A8DFE43187372281B718719380FCB968. doi:10.1017/S0266466617000056

32. Steger, C., Hirsch, S., Evers, C., Branoff, B., Petrova, M., Nielsen-Pincus, M., . . . Van Riper, C. J. (2018). Ecosystem services as boundary objects for transdisciplinary collaboration. Ecological economics, 143, 153-160. doi:https://doi.org/10.1016/j. ecolecon.2017.07.016

33. Treacy, P., Jagger, P., Song, C., Zhang, Q., \& Bilsborrow, R. E. (2018). Impacts of China's Grain for Green Program on Migration and Household Income. Environmental management, 62(3), 489-499. doi:https://doi.org/10.1007/s00267$\underline{018-1047-0}$

34. Vietnam Administration of Forestry. (2019). The report on operation results of the forestry sector in 2018-2019. Retrieved from http://tongcuclamnghiep.gov.vn/ LamNghiep/Index/diem-bao-ngay-29102018-3867

35. Wang, Y., Bilsborrow, R. E., Zhang, Q., Li, J., \& Song, C. (2019). Effects of payment for ecosystem services and agricultural subsidy programs on rural household land use decisions in China: Synergy or trade-off? Land use policy, 81, 785-801. doi:https://doi.org/10.1016/j.landusepol.2018.10.057

36. Watson, J. E. M., Evans, T., Venter, O., Williams, B., Tulloch, A., Stewart, C., . . Lindenmayer, D. (2018). The exceptional value of intact forest ecosystems. Nature Ecology \& Evolution, 2(4), 599-610. Retrieved from https://doi.org/10.1038/ s41559-018-0490-X. doi:10.1038/s41559-018-0490-X 
37. Yitzhaki, S. (1994). Economic distance and overlapping of distributions. Journal of Econometrics, 61(1), 147-159. doi:https://doi.org/10.1016/0304-4076(94)90081-7

38. Zhou, M., Wang, F., \& Wang, K. (2019). Destination Service Encounter Modeling and Relationships with Tourist Satisfaction. Sustainability, 11(4), 960. 